Научная статья

УДК 343.2.01

https://doi.org/10.24866/1813-3274/2021-3/124-139

\title{
СТАНОВЛЕНИЕ В РОССИИ ДОКТРИНЫ УГОЛОВНОГО ПРАВА, ЕГО ПРЕДМЕТА И МЕТОДА
}

\author{
А. И. Чучаев ${ }^{1}$, Институт государства и права Российской академии наук, \\ г. Москва, Россия \\ E-mail: moksha1@rambler.ru
}

Аннотациия. Статья посвящена хотя и взаимосвязанным, но самостоятельным проблемам, практически не подвергавшимся исследованию в советском и постсоветском уголовном праве: наименованию отрасли права, его истокам и толкованию; понятию и характеристике уголовного права как отрасли права и как отрасли науки, предмету и методу последней в творческом наследии криминалистов России XIX в. Проанализированы взгляды М. В. Духовского, В. В. Есипова, А. Ф. Кистяковского, А. А. Пионтковского (отца), П. П. Пусторослева, Н. Д. Сергеевского, Г. И. Солнцева, В. Д. Спасовича, Н. С. Таганцева, М. П. Чубинского и др. На основании проведённого исследования сделан вывод о том, что в российской доктрине уголовного права сформировались два подхода к определению науки уголовного права: широкий и узкий. Содержание науки уголовного права было подчинено её практической цели - дать руководство к правильному пониманию и применению, критике и составлению уголовного закона.

Ключевые слова: уголовное право, истоки наименования, этимология, лексическое значение, уголовное право как отрасль права, соотношение с другими отраслями права, уголовное право как отрасль науки, понятие, предмет, метод.

Для циитирования: Чучаев А. И. Становление в России доктрины уголовного права, его предмета и метода // Азиатско-Тихоокеанский регион: экономика, политика, право. 2021. № 3. С. 124-139. https://doi.org/10.24866/1813-3274/2021-3/124-139.

\footnotetext{
1 Александр Иванович Чучаев, доктор юридических наук, профессор, заведующий сектором уголовного права, уголовного процесса и криминологии, Институт государства и права Российской Академии наук, г. Москва, Россия.

(C) Чучаев А. И., 2021
} 
Original article

\title{
THE FORMATION OF DOCTRINE IN RUSSIA CRIMINAL LAW, ITS SUBJECT AND METHOD
}

\author{
Alexander I. Chuchaev ${ }^{1}$, Institute of State and Law of the Russian Academy \\ of Sciences, Moscow, Russia \\ E-mail: moksha1@rambler.ru
}

Abstract. The article is devoted to independent, albeit interrelated problems that were almost never studied in the Soviet and post-Soviet criminal law: the name of the branch of rights, its origins and interpretation; the concept and characteristics of criminal law as a branch of law and as a branch of science, the subject and method of the latter in the creative heritage of Russian forensic scientists in the 19th century. The views of M. V. Dukhovsky, V. V. Esipov, A. F. Kistyakovsky, A. A. Piontkovsky (father), P. P. Pustoroslev, N. D. Sergeevsky, G. I. Solntsev, V. D. Spasovich, N. S. Tagantsev, M. P. Chubinsky and others. This study resulted in the conclusion that two approaches to the definition of the science of criminal law were formed: broad and narrow. The content of the science of criminal law was subordinated to its practical goal - to provide guidance on the correct understanding and application, criticism and drafting of criminal law.

Keywords: criminal law, the origins of the name, etymology, lexical meaning, criminal law as a branch of law, correlation with other branches of law, criminal law as a branch of science, concept, subject, method.

For citing: Chuchaev A. I. The formation of doctrine in Russian criminal law, its subject and method // PACIFIC RIM: Economics, Politics, Law. 2021. No. 3. P. 124139. https://doi.org/10.24866/1813-3274/2021-3/124-139.

Название отрасли права, регулирующей отношения, связанные с совершением преступления, его происхождение и время появления относятся к числу дискуссионных проблем. В зарубежных странах с давних времен сложились два основных подхода к наименованию этой отрасли: в одних случаях во главу угла ставится преступление, и исходя из этого формулируется его название; сказанное в большей степени присуще англоязычным государствам (например, в Австралии, Великобритании, США - criminal law). В других случаях за основу берётся наказание; по такому принципу определяется наименование в других странах (например, в Германии - strafrecht, в Болгарии - наказателно право, в Македонии - казнено право и

\footnotetext{
${ }^{1}$ Alexander I. Chuchaev, Doctor of Law, Professor, Head of the Sector of Criminal Law, Criminal procedure and Criminology, The Institute of State and Law of the Russian Academy of Sciences, Moscow, Russia.
} 
др.). Есть и третий вариант, в котором рассматриваемое понятие образовано от вины - кривично право (кривица - вина, а также проступок, преступление в зависимости от контекста, но чаще всего именно вина) [3, с. 14].

Характеризуя сложившуюся ситуацию, Н. С. Таганцев отмечал: «Преступное деяние как юридическое отношение заключает в себе два отдельных момента: отношение преступника к охраняемому законом юридическому интересу - преступление и отношение государства к преступнику, вызываемое учиненным им преступным деянием, - наказание, поэтому и уголовное право может быть конструировано двояко: или на первый план ставится преступное деяние, по отношению к которому кара или наказание является более или менее неизбежным последствием, или же вперёд выдвигается карательная деятельность государства и преступное деяние рассматривается только как основание для этой деятельности. Отсюда и двойственное название...» [21, с. 27].

Как указывается в литературе, название рассматриваемой отрасли права имеет опосредованное отношение как к преступлению, так и к наказанию [14, с. 9]. Прилагательное «уголовный» известно в русском и белорусском языках, образовано от головьный - «убивающий», зафиксированный в древнерусских памятниках и являющийся производным от «голова» - «убитый» (древнерусский головьникъ - убийца) $[8$, с. 460]. При этом, как отмечается в словарях, происхождение самого слова «голова» неясно [8, с. 108]. Таким образом, с одной стороны, название отрасли восходит к правовым памятникам Древней Руси. С другой стороны, оно, скорее всего, имеет корни в латыни; латинское прилагательное capitalis (от caput - голова, человек, индивидуум) в римском праве входит в название наказаний, связанных со смертной казнью, лишением свободы или римского гражданства.

В средневековой литературе (XVI в.) достаточно часто встречается слово «уголовие», употреблявшееся в значении «лишение жизни» или «лишение головы».

Скорее всего, термин «уголовное наказание» в правовую литературу впервые ввёл М. М. Сперанский. В пояснениях к проекту Уголовного уложения Российской Империи он писал, что уголовные наказания «суть те, где дело идёт о голове, то есть о жизни ... а жизнь каждого лица в обществе есть троякая: физическая, политическая и гражданская, две последние именуются правами состояния. Всякое наказание, непосредственно удручающее или умаляющее бытие или состояние лица, есть наказание уголовное» [21, с. 57].

В настоящее время уголовное право понимается в одном из трёх значений: вопервых, как отрасль права; во-вторых, как отрасль науки; в-третьих, как учебная дисциплина. В дореволюционной литературе термин «уголовное право» использовался только в первых двух значениях.

А. Ф. Бернер писал: «На входных вратах излагаемой науки должно быть прежде всего написано её понятие» [1, с. 4]. Однако учёные прошлых веков практически не 
исследовали уголовное право как отрасль права. Те же криминалисты, которые упоминали его в этом значении, ограничивались краткой дефиницией. Например, Г. И. Солнцев посчитал возможным лишь указать, что «систематическое начертание истин, из самых законов извлеченных, о неправомерных деяниях граждан, противу общей или частной безопасности устремляемых, и определяющих соразмерные за оные наказания, называется в ближайшем смысле Уголовныл правом...» [19, с. 2].

Сам А. Ф. Бернер, исходя из сути названия отрасли права как strafrecht, выделял два значения уголовного права: во-первых, в субъективном смысле, понимая его как право государства на наказание (jus puniendi); во-вторых, в объективном смысле, понимая его как совокупность тех основных положений, которыми должно руководствоваться государство при осуществлении своего карательного права [1, с. 4].

В. Д. Спасович писал: «Совокупность законов, определяющих правила, по которым действует правительство в государстве при производстве уголовных взысканий с нарушителей общественного порядка, называется уголовным правом» [20, с. 2]. Автор отмечает, что уголовное право как законодательство положительное есть часть всего законодательства какого-либо государства, в котором определяются преступления. Оно подразделяется на материальное и формальное. «Первое из них, или уголовное право в тесном смысле, заключает в себе все законы, определяющие преступления и соответствующие этим преступлениям наказания. Уголовное право формальное, или уголовное судопроизводство, есть совокупность законов, определяющих формы, обряды и приёмы, употребляемые органами уголовной власти государства при применении уголовных законов к отдельным совершённым в обществе преступлениям» [20, с. 3]. Материальное уголовное право делится на две части: Общую и Особенную. «Общая часть рассматривает закон уголовный, преступление и наказание как общие, родовые понятия. Особенная часть от этих общих понятий переходит к частностям и излагает отдельные виды преступлений и их наказуемость» [20, с. 3].

В определении места уголовного права в системе законодательства положительного В. Д. Спасович, на наш взгляд, был недостаточно последователен. С одной стороны, он считал, что карательное право, куда автор включал уголовное и дисциплинарное право, полностью относится к области общественного права (в современном понимании - публичного), «потому что оно есть право, принадлежащее обществу как целому, и существует в видах охранения общественного порядка от посягательств на него со стороны отдельных неделимых». С другой стороны, утверждал, что уголовное право примыкает к частному праву в области правонарушений и суда. «Правонарушение есть общее родовое понятие, заключающее в себе и правонарушения частные, подсудные суду гражданскому, и преступления уголовные, подсудные судам уголовным» [20, с. 4, 5].

А. А. Пионтковский (отец), следуя установившейся традиции, в учебнике по уголовному праву определению последнего как отрасли права посвятил всего две 
страницы, причем расположив их после изложения материала об уголовном праве как науке. Надо сказать, что в целом автор достаточно близко подошёл к современному понятию уголовного права как отрасли права, выделив в его определении совокупность юридических норм, меры воздействия, которые могут применяться к виновным, условия их реализации. Он пишет: «Комплекс юридических норм, устанавливающих допустимые в борьбе с преступниками меры воздействия и определяющих условия применения этих мер, образует из себя материальное уголовное право, или уголовное право в тесном смысле слова» [11, с. 32].

В этом высказывании обращают на себя внимание по крайней мере два момента: во-первых, в дефиниции не упоминается преступление, а говорится о преступниках; во-вторых, автор, как и другие дореволюционные криминалисты, уголовное право воспринимал в качестве родового понятия, охватывающего два видовых: уголовное право в тесном смысле слова, другими словами - материальное уголовное право, и формальное уголовное право, иначе говоря - уголовно-процессуальное право.

По мнению А. А. Пионтковского, уголовное право, являясь публичной отраслью, регулирует одну из существенных функций государственной власти [11]. Это утверждение вызывает вопросы, поскольку оно на первый взгляд больше, пожалуй, относится к уголовному процессу, регламентирующему деятельность соответствующих органов власти, связанную с раскрытием, расследованием и рассмотрением дела в суде. К сожалению, сам автор не раскрывает сути указанной функции, однако скорее всего речь идёт о противодействии преступности. Об этом свидетельствует его следующее высказывание: «Представляясь не чем иным, как правом, специально охраняющим индивидуальные и коллективные интересы от преступных, уголовное право содействует усилению и укреплению той охраны этих интересов, какая предоставляется господствующим правопорядком вообще» [11].

А. Ф. Кистяковский, рассматривая уголовное право в двух первых его значениях, определяет их, во-первых, как «совокупность законов, относящихся до преступлений и наказаний»; во-вторых, как науку, «которая исследует, определяет и излагает понятия о преступлении и наказании». Отрасль права появляется раньше, отрасль науки - позднее, что объясняется их сущностью. «Что появление уголовного права как науки относится к более позднему времени, чем было то время, когда появилось уголовное право как совокупность законов и обычаев, - это до очевидности ясно и неоспоримо. Положение это подтверждается неоспоримыми историческими данными. Даже появление науки права вообще ... нельзя ... принимать за появление вместе с тем и науки уголовного права ... Причина такого различия во времени появления того и другого заключается в различии свойств уголовного права как совокупности законов и уголовного права как науки. Первое создаётся непосредственною деятельностью человека и даже на низших ступенях развития ... Второе для своего создания требует значительной степени развития обобщающей и 
систематизирующей мыслительной способности человека...» [7, с. 3, 5]. Наука, подчёркивает автор, является произведением высшего порядка и «более стройных чувств человека» $[7$, с. 6].

Надо заметить, что А. Ф. Кистяковский выделял два вида изучения уголовного права как отрасли права: практическое и теоретическое, т. е. говорил о его «двуликости» [2, с. 79-80]. Практическое изучение уголовных законов достигается путём отправления той или другой судебной деятельности в обширном смысле этого слова. Теоретическое познание уголовных законов, дающее в результате науку уголовного права в тесном смысле, приобретается только их специальным изучением [7, с. 2].

П. А. Фейербах считал неудачным наименование первого вида (практического) изучения уголовного права. Он исходил из того, что предметом так называемой практической науки могут быть только искусственные правила (делопроизводство). Следовательно, и практическая часть уголовного права состоит, во-первых, из науки об искусственных правилах, которые служат руководством к исследованию, во-вторых, теории искусственных правил, используемых по уголовным делам, знания о том, как докладывать и сочинять определения, и знания о ведении и регистрации дел. По мнению автора, в науку уголовного права в собственном смысле слова, помимо различных частей положительного права, необходимо включать:

1) философию, относя к ней психологию (душесловие);

2) практическую философию, включая в неё а) право естественное и б) всеобщее уголовное право;

3) уголовную политику, охватывающую исторические науки вообще и историю соответствующего государства в частности;

4) зарубежное законодательство;

5) судебную врачебную науку (судебную медицину) [22, с. 5-7].

П. П. Пусторослев воспринимал уголовное право в обширном смысле как «совокупность правил права, определяющих правомерную борьбу государства и частных лиц против уг.[оловных] правонарушителей и уг.[оловных] правонарушений, или, короче говоря, против преступлений и преступников» $[13$, с. 9]. Критикуя деление уголовного права в широком смысле на две ветви - собственно уголовное право и уголовно-судебное право, автор замечает, что оно представляется более сложным явлением, объединяющим четыре тесно связанные между собой составные части:

1) уголовно-определительное, или уголовное право, определяет в общем виде содержание уголовных правонарушений и установленных за них наказаний в государстве;

2) уголовно-охранительное право устанавливает в общем виде: кому, при каких условиях и какими способами надлежит устранять будущие и прекращать происходящие уголовные правонарушения и их неправомерные последствия, выгодные правонарушителю; 
3) уголовно-судебное право определяет в общем виде систему органов и их деятельность по отправлению уголовного правосудия в государстве или, «иначе сказать, определяет, каково должно быть отправление уг.[оловного] правосудия в государстве и каким органам вручено производство этой деятельности»;

4) уголовно-исполнительное право определяет в общем виде «кому, при каких условиях и какими способами надлежит приводить в исполнение правомерные оправдательные, освободительные и наказательные приговоры и определения, а также правомерные распоряжения о принудительных мерах по уг.[оловным делам]» $[13$, с. $11-12]$.

Нетрудно заметить, что в этом случае автор сводит воедино, исходя из современного отраслеообразования, три отрасли права: уголовное, уголовнопроцессуальное, уголовно-исполнительное, а также, судя по всему, криминологию (уголовно-охранительное). Подобный подход не только затушёвывает различия между указанными отраслями права и криминологией, но, главное, не позволяет показать специфические черты собственно уголовного права.

Как уже говорилось, в дореволюционной литературе бо́льшее внимание уделялось уголовному праву как отрасли науки. Именно с её характеристики практически начинаются все работы криминалистов того времени [9]*. Например, П. А. Фейербах пишет: «Уголовное право (наука о наказательном праве) есть знание существующих в Государстве прав, основанных на законах наказательных относительно к подданным как нарушителям сих законов» [22, с. 1].

В российской доктрине уголовного права в целом сформировались два подхода к определению науки: широкий и узкий. Первый исходит из того, что предмет науки охватывает всё, что связано с изучением борьбы с преступностью. Иначе говоря, с современных позиций можно утверждать, что имеет место симбиоз уголовного права (уголовная догматика), криминологии и уголовной политики. При этом, например, А. А. Пионтковский выделяет три аспекта исследования последней: социологический, уголовно-догматический и уголовно-политический. С социологической точки зрения вопросы борьбы с преступностью рассматриваются как реальные факты общественной жизни в их динамическом и статическом отношениях, выявляется эволюционный процесс развития и образования, раскрываются естественные законы, обусловливающие их рост и проявление, а также характер, роль и значение в определённой социальной среде. С уголовно-догматической точки зрения внимание исследователя сосредоточивается на изучении той «юридической оболочки», в которую эти явления облечены, уяснении процесса образования тех юридических норм, которыми регулируется борьба с преступностью, выявлении

\footnotetext{
* Кстати сказать, курс советского уголовного права также открывается разделом «Введение в теорию советского уголовного права», первая глава которого посвящена предмету, методу и содержанию науки советского уголовного права.
} 
характера и особенностей этих норм, на их конструировании и систематизации. Наконец, с уголовно-политической точки зрения анализируется весь механизм борьбы с преступностью, его соответствие интересам этой борьбы и потребностям общественной жизни, определяются основы, на которых покоится данный механизм, и формы его функционирования, т. е. «тот идеал, сообразно которому должно бы организовать дело борьбы с преступностью» [12, с. 13].

Возражая Н. Д. Сергеевскому, Н. С. Таганцеву и другим криминалистам, считавшим, что исследования по криминологии (уголовной социологии, уголовной антропологии), уголовной политике и уголовной догматике нельзя соединять воедино в рамках одной науки из-за существующего между ними различия в методах и преследуемых задачах, А. А. Пионтковский отмечал: «Метод исследования не представляется характерным признаком отличия одной науки от другой, так как всякая наука пользуется для своих исследований, по мере надобности, то тем, то другим методом - то индукцией, то дедукцией. Наконец, что касается методологии в науке уголовного права, то нельзя не заметить, что эта наука даже и до образования криминологических и уголовно-политических доктрин не могла всегда оперировать при посредстве одной дедукции, а пользовалась в широких размерах и индуктивным методом...» [11].

По мнению автора, при сравнении задач рассматриваемых наук действительно обнаруживаются некоторые различия между ним, но эти различия обусловлены не тем, что криминология (уголовная социология, уголовная антропология), уголовная политика и уголовная догматика являются самостоятельными отраслями наук, а тем, что любая наука, а не только названные, стремясь к определённой цели, разрешает целую совокупность крайне разнородных, но тесно взаимосвязанных между собой задач. При этом цель остаётся одной и той же [11].

В то же время интеграция исследований по указанным направлениям обусловлена основным негативным явлением общественной жизни - преступлением, все они изучают один и тот же объект - проблемы борьбы с преступностью, выделяя его составные части, и направлены к достижению единого общего результата [11].

Несколько ранее М. В. Духовской также утверждал: «Уголовное право изучает преступление, узнаёт причины его появления и указывает государству средства, годные к предупреждению этого явления» [4, с. 220]. Исходя из этого, автор считал, что взгляд на уголовное право как на науку, изучающую только преступление и наказание, является неверным. Сравнивая уголовное право с медициной, доказывал, что как медицина лечит больной организм, так и уголовное право исцеляет общественный строй, избавляет его от преступления, являющегося не чем иным, как болезнью в правильной общественной жизни. «Поскольку такое сравнение уместно, то несправедливо лишать науку уголовного права одной из задач, стоящей перед медицинской наукой. Не только лечить уже заболевший организм, но и изу- 
чать болезнь, побудившие её причины и указывать средства, предотвращающие появление болезни. В этом плане уголовное право также должно изучать преступление, узнавать причины его появления и указывать государству средства, годные к предупреждению этого явления» [4, с. 221].

Оригинальную точку зрения о науке уголовного права высказывал В. В. Есипов. При этом надо иметь в виду, что автор несколько раз менял своё мнение. Так, вначале он, критикуя в первую очередь за односторонность уголовно-антропологическое и уголовно-социологическое направления, считал, что «уголовное право есть наука о преступлении и преступнике, о наказании и наказуемом» [5, с. 26]. Позднее определял указанную науку несколько иначе. Делая акцент на её гуманитарном аспекте, В. В. Есипов представлял её как науку «о человеке ... о способах возрождения нравственно падшего человека» [6, с. 12]. Эта дефиниция вряд ли дает представление о сути рассматриваемой науки, её предмете, методах, функциях и задачах. Будучи достаточно экспрессивной, она, скорее, отражает образность мышления автора, искренне проповедующего гуманизм, «идущего под знаменем цивилизации».

Обстоятельную характеристику уголовное право как отрасль науки получило как в работах, специально посвящённых этой проблеме, так и в пособии к лекциям Н. Д. Сергеевского $[15 ; 16 ; 17 ; 18]$. При оценке позиции учёного необходимо иметь в виду, что в целом он тяготел к историко-сравнительному направлению в уголовном праве. Однако многие проблемы рассматривал с точки зрения позитивизма, а ряду его работ присущ научно-догматический метод.

Это обстоятельство отразилось и на формулируемом им понятии науки уголовного права. Н. Д. Сергеевский писал: «Наука уголовного права есть одна из наук юридических, имеющая своим предметом то явление государственной жизни, которое мы называем преступным деянием и наказанием. Исследуя юридическую природу преступного деяния и наказания и формулы права, эту природу определяющие, наука уголовного права служит практической цели - дать руководство к правильному пониманию и применению, критике и составлению уголовного закона. Этим определяется содержание уголовного права как науки юридической» [10; 15]. Исходя из указанного понимая уголовно-правовой науки, автор её содержание трактует достаточно широко, включая в него:

- учение об общем и о специальном составе преступных деяний;

- учение об уголовном законе, его конструкции и условиях применения;

- учение о наказании.

Таким образом, содержание науки уголовного права было подчинено её практической цели - дать руководство к правильному пониманию и применению, критике и составлению уголовного закона.

Источником уголовно-правовой науки Н. Д. Сергеевский признавал «уголовные законы в обширном смысле слова» а) законы писаные; б) история их текста; в) 
законы, установленные обычаем, если они признаются положительным правом; г) применение уголовных законов на практике. Однако, как он считал, этого недостаточно для полной реализации целей науки; «никакие логические операции над одними формулами положительного уголовного права не приведут исследователя к выполнению научных задач в вопросах de lege lata, так тем более в вопросах de lege ferenda. Для этого необходимо привлечь массу другого материала и неукоснительно пользоваться им для построения выводов и обобщений» [17, с. 2]. Именно поэтому в число источников науки уголовного права он включал:

- законодательство иных отраслей права, без которых невозможно определить сущность уголовно-правового положения, т. е. межотраслевые связи уголовного права;

- зарубежное законодательство; его изучение обусловлено тем, что «цивилизованным народам ... не суждена замкнутая жизнь; международные влияния проникают во все сферы, и игнорировать их мы не можем ... Постоянные международные сношения имеют своим последствием развитие целого ряда, так сказать, общенародных институтов, которые нисколько не мешают самостоятельному развитию учреждений национальных, но для собственного своего приложения и понимания требуют знакомства с правом других стран»; главное в этом случае «заключается в том, чтобы не дать чужеземному материалу того значения, которого он иметь не должен»;

- бытовой материал, т. е. господствующие в обществе правовоззрения, не нашедшие отражения в праве. Он необходим как для совершенствования уголовного законодательства, так и для его применения, например, «законодатель не должен устанавливать таких форм наказаний, которые противны народному правосознанию, хотя бы сам законодатель был убеждён в полной допустимости и полезности этих наказаний»;

- специальные исследования в области физиологии, психологии, психиатрии и других наук, необходимые для закрепления в законе положений о субъективных условиях вменения, способности к вменению и невменяемости малолетних [17, с. 2-14].

В отличие от А. А. Пионтковского, Н. Д. Сергеевский считал, что всякая наука определяется тремя моментами: предметом, целью и методом. «При тождестве этих трех моментов в каких-либо двух исследованиях мы можем сказать, что оба эти исследования входят или должны войти в состав одной и той же науки, и наоборот, если эти три момента различествуют, то и исследования, о которых идёт речь, не могут быть соединены воедино, в одну цельную систему» [17, с. 15].

Предмет и цель науки уголовного права, как было показано, автор включал в дефиницию последней, а характеристику её методов сопровождал сравнением с методами других наук, которые, так или иначе, соприкасаются с уголовно-правовой наукой: социологией, биологией и т. д. [17, с. 15].

Взгляды учёного будут представлены не полно, если не упомянуть хотя бы о его позиции относительно качества науки уголовного права, её противопоставле- 
нии философским направлениям и приёмам, способным не только к крупным логическим построениям, но и, по мнению Н. Д. Сергеевского, к выдвижению множества «более мелких изобретений, которые вырастают и пропадают в доктрине как метеоры или, вернее, как мыльные пузыри, не оставляя после себя ничего, кроме недоразумений» $[18$, с. 80]. Эти «пузыри», или «родные дети философии», рассеянные по различного рода компендиумам, заслуженно выработали к себе отрицательное отношение юридической практики.

Надо сказать, что подобная оценка присуща не только Н. Д. Сергеевскому. Немецкий учёный А. Шютце, на которого ссылается последний, также утверждал, что «практика видит в доктринальных построениях карточный дом, воздушный замок или массу дождевой воды, которая образует грандиозное озеро весною и пропадает летом. Горький опыт сделал практику недоверчивой, чтобы не сказать запуганной» [18, с. 81].

Таким образом, автор отказывал философии в существовании в науке уголовного права. Пожалуй, в том числе и поэтому последнюю противопоставлял другим социальным наукам - социологии и антропологии, видя в первой скорее искусство, чем доктрину, и в то же время подчёркивал их самостоятельность и определённую взаимосвязь. «Искусство опирается на науку, - писал Н. Д. Сергеевский, - и, в свою очередь, наука не будет приведена к своей конечной цели без искусства. Наука исследует законы явлений, искусство пользуется их познанием для практических целей» [15, с. 890].

В творческом наследии Н. С. Таганцева нет работ, специально посвящённых проблемам науки уголовного права. Это, разумеется, нисколько не означает, что учёный игнорировал вопросы собственной уголовно-правовой теории; он к ним обращался во многих своих работах, при этом особое внимание уделял методам научного исследования. Можно сделать вывод, что уголовное право как отрасль науки он трактовал в целом так же, как, например, А.Ф. Кистяковский. «...Уголовное право, - пишет Н. С. Таганцев, - как одна из юридических наук должно ... иметь своим предметом изучение преступных деяний как юридических отношений». Автор замечает, что это положение считалось сакраментальным в науке. «Разнообразная деятельность, направленная к удостоверению учинения ... лицом преступного деяния, установление его виновности и осуждение, порядок определения соответственно закону рода и меры ответственности, выбор законодателем известных карательных мер, годных для действительной охраны общественного порядка и спокойствия, распределение этих мер как кары за отдельные деяния сообразно их важности и свойствам, наконец, само выполнение этих мер, в особенности, например, лишения свободы и т. д., - всё это даёт не только разнообразный, но во многих отношениях и своеобразный жизненный юридический материал, систематическое изучение которого вполне пригодно дать содержание самостоятельной отрасли юридических наук - уголовному праву...» [21, с. 8, 9]. 
Во второй половине XIX в. в уголовно-правовой литературе в целом сформировались два подхода к сущности науки уголовного права. Одни учёные считали предмет последней существенно зауженным, поэтому на первый план предлагали выдвинуть не правовые, а социально-антропологические объяснения преступности, вместо метафизическо-юридических построений исследовать суть действительных явлений и законов, их регулирующих. Другие считали необходимым в предмет уголовного права включить социологию и антропологию; другими словами, преступление и преступника изучать с юридических, социальных и биологических позиций [23]. Критикуя эти подходы, Н. С. Таганцев обращает внимание на то, что социологическое, антропологическое и юридическое исследование преступления и преступника в рамках одной науки теоретически не соответствует основным началам классификаций отдельных отраслей знания, а на практике принесёт взаимный вред указанным наукам, так как они различаются методами и приёмами анализа фактического материала и по реализуемым целям [21, с. 9, 10].

Поэтому предметом науки уголовного права как таковой «должно быть изучение юридической конструкции преступных деяний и вызываемой ими карательной деятельности государства, изучение совокупности норм, определяющих наказуемость преступных деяний», а предметом русской науки уголовного права - «изучение действующих в России постановлений о преступных деяниях и их наказуемости вообще, так и в отдельных родах и видах» [21]. Данное определение не только раскрывает содержание науки уголовного права, но и позволяет отграничивать её от уголовного процесса.

Методы науки уголовного права относились к числу дискуссионных вопросов, причём именно здесь, в отличие от иных отраслей правовых наук, имелся наибольший разброс мнений. Особый интерес представляют два метода, в первую очередь из-за их диаметрально противоположного характера: во-первых, отвлечённый, или метафизический; во-вторых, так называемый положительный. Сторонники первого из них предпринимали попытки сформулировать все положения теории преступления и наказания исходя из дедуктивного метода, из а priori установленного понятия преступного, сущности карательной деятельности, условий гарантий личности и т. д. независимо от действующих законов соответствующего государства. Представители так называемого положительного метода уголовно-правовых исследований берут за отправную точку реально существующие уголовно-правовые отношения и строят не только учение об отдельных видах преступных деяний, но и общее учение о преступлении и наказании на основании уголовного законодательства, практики его применения, положений обычного права и т. д. По мнению Н. С. Таганцева, такой подход является предпочтительным и преобладающим в науке уголовного права [21]. 


\section{Список литературы}

1. Бернер, А. Ф. Учебник уголовного права : части общая и особенная / А.Ф. Бернер ; с примечаниями, приложениями и дополнениями по истории русского права и законодательству положительному магистра уголовного права Н. Неклюдова ; пер. и изд. Н. Неклюдова. - Санкт-Петербург : [В тип. Н. Тиблена и комп. (Н. А. Неклюдова)], 1865. - VIII, 160 с.

2. Бочкарев, С. А. Гносеология уголовного права / С. А. Бочкарев. - Москва, 2021. $-664 \mathrm{c}$.

3. Голик, Ю. Понятие и происхождение названия «уголовное право» / Ю. Голик, С. Елисеев // Уголовное право. - 2002. - № 2. - С. 14-16.

4. Духовской, М. В. Задачи науки уголовного права : вступительная лекция, читанная 3 октября 1872 г. // Временник Демидовского юридического лицея. Ярославль, 1873. - Кн. 4. - С. 220-252.

5. Есипов, В. В. Очерк русского уголовного права. Часть общая : преступление и преступники. Наказание и наказуемые / В. В. Есипов. - Санкт-Петербург : Тип. Н. В. Васильева, 1898. - 402 с.

6. Есипов, В. В. Очерк русского уголовного права. Часть общая : преступление и преступники. Наказание и наказуемые. - 3-е изд., пересм. и доп., согласно Уголовному уложению 1903 г. и последним узаконениям / В. В. Есипов. - Москва : Книжный магазин «Правоведение» И. К. Голубева, 1904. - 550, V c.

7. Кистяковский, А. Ф. Элементарный учебник общего уголовного права с подробным изложением начал русского уголовного права. Часть Общая / А. Ф. Кистяковский. - Киев : Ф. А. Иогансон, 1891. - 892 с.

8. Краткий этимологический словарь / под ред. С. Г. Бархударова. - Москва, 1971. -542 c.

9. Курс советского уголовного права : в 6 т. Т. 1. - Москва, 1970. - 311 с.

10. Набоков, В. Д. Содержание и метод науки уголовного права // Журнал Юридического общества. - 1896. - Декабрь. - С. 52-71.

11. Пионтковский, А. А. Наука уголовного права. Её предмет, задачи, содержание и значение : вступительная лекция, читанная в Демидовском юридическом лицее 15 сентября 1895 г. // Избранные труды: в 2 т. Т. $1 /$ А. А. Пионтковский ; сост. Ф. Р. Сундуров, М. В. Талан. - Казань : Изд-во Казан. ун-та, 2004. - С. 179-192.

12. Пионтковский, А. А. Уголовное право (пособие к лекциям). Часть Общая. Вып. 1 / А. А. Пионтковский. - Казань : Типо-литография Императорского Казанского университета, 1913. - $126 \mathrm{c}$.

13. Пусторослев, П. П. Русское уголовное право. Общая часть. Вып. $1 /$ П. П. Пусторослев. - 2-е изд., испр. - Юрьев, 1912. - 252 с. 
14. Российское уголовное право. Общая часть / под ред. В. С. Комиссарова. Санкт-Петербург, 2005. - 560 с.

15. Сергеевский, Н. Д. Преступление и наказание как предмет юридической науки (задачи науки уголовного права) // Юридический вестник. - 1879. - Кн. 12. С. 876-904.

16. Сергеевский, Н. Д. Программа науки уголовного права // Временник Демидовского юридического лицея. - 1879. - Кн. 20. - С. 356-382.

17. Сергеевский, Н. Д. Русское уголовное право. Часть общая : пособие к лекциям / Н. Д. Сергеевский. - 4-е изд. - Санкт-Петербург : типография М. М. Стасюлевича, 1900. - VIII, 364 с.

18. Сергеевский, Н. Д. Философские приёмы и наука уголовного права // Журнал гражданского и уголовного права. -1879. - Кн. 1. - С. 39-87.

19. Солнцев, Г. И. Российское уголовное право / Г. И. Солнцев ; под ред. Г. С. Фельдштейна. - Ярославль : Демидовский юридический лицей, 1820. - 302 с.

20. Спасович, В. Д. Учебник уголовного права. Т. 1 : (Общая часть уголовного права материального). Вып. 1 / В. Д. Спасович. - Санкт-Петербург : Тип. И. Огризка, 1863. - 438 с.

21. Таганцев, Н. С. Русское уголовное право. Часть Общая : в 2 т. Т. 1 / Н. С. Таганцев. - Тула, 2001. - 800 с.

22. Фейербах, П. А. Уголовное право / П. А. Фейербах. - Санкт-Петербург : Медицинская тип., 1810. - 486 с.

23. Чубинский, М. П. Общая характеристика новых учений в уголовном праве : вступительная лекция / М. П. Чубинский. - Киев : Типография Императорского Университета Св. Владимира Н. Т. Корчак-Новицкого, 1898. - 24 с.

\section{References}

1. Berner A. F. Uchebnik ugolovnogo prava: chasti obshchaya $i$ osobennaya / $s$ primechaniyami, prilozheniyami $i$ dopolneniyami po istorii rusckogo prava $i$ zakonodatel'stvu polozhitel'nomu magistra ugolovnogo prava N. Neklyudova [Criminal Law Textbook: General and Special Parts. With notes, appendices and additions on the history of rus. law and legislation positive master of criminal law N. Neklyudova; transl. and ed. N. Neklyudova]. St. Petersburg: [B type. N. Tiblena and comp. (N.A. Neklyudova)], 1865. VIII, $160 \mathrm{p}$.

2. Bochkarev S. A. Gnoseologiya ugolovnogo prava [Gnoseology of criminal law]. Moscow, 2021. 664 p.

3. Golik Y., Eliseev S. Ponyatie i proiskhozhdenie nazvaniya «ugolovnoe pravo» [Concept and origin of the name «criminal law»]. Ugolovnoe pravo, 2002, no. 2, pp. 14-16.

4. Dukhovskoy M. V. Zadachi nauki ugolovnogo prava: vstupitel'naya lektsiya, chitannaya 3 oktyabrya $1872 \mathrm{~g}$. [Tasks of the science of criminal law. Introductory lecture, 
read on October 3, 1872]. Vremennik Demidovskogo yuridicheskogo litseya: Yaroslavl, 1873, book. 4, pp. 220-252.

5. Esipov V. V. Ocherk russkogo ugolovnogo prava. Chast' obshchaya: prestuplenie i prestupniki. Nakazanie i nakazuemye [Essay on Russian criminal law. Common part: crime and criminals. Punishment and punishable]. St. Petersburg: Type. N.V. Vasilieva, 1898. $402 \mathrm{p}$.

6. Esipov V. V. Ocherk russkogo ugolovnogo prava. Chast' obshchaya: prestuplenie i prestupniki. Nakazanie i nakazuemye [Essay on Russian criminal law. Common part: crime and criminals. Punishment and punishable]. 3rd ed., rev. and additional, according to the Criminal Code of 1903 and the latest legalizations. Moscow: Bookstore «Jurisprudence» I.K. Golubev Publ., 1904. 550, V p.

7. Kistyakovsky A. F. Elementarnyi uchebnik obshchego ugolovnogo prava s podrobnym izlozheniem nachal russkogo ugolovnogo prava. Chast' Obshchaya [Elementary textbook of general criminal law with a detailed presentation of the beginnings of Russian criminal law. Part General]. Kiev: F. A. Ioganson Publ., 1891. 892 p.

8. Barkhudarov S. G. (ed.). Kratkii etimologicheskii slovar' [Brief etymological dictionary]. Moscow, 1971. $542 \mathrm{p}$.

9. The course of the Soviet criminal law: in 6 volumes. Vol. 1. Moscow, 1970. 311 p. (In Russian).

10. Nabokov V. D. Soderzhanie i metod nauki ugolovnogo prava [Content and method of science of criminal law]. Zhurnal Yuridicheskogo obshchestva, 1896, December, pp. 52-71.

11. Piontkovsky A.A. Nauka ugolovnogo prava. Ee predmet, zadachi, soderzhanie i znachenie : vstupitel'naya lektsiya, chitannaya v Demidovskom yuridicheskom litsee 15 sentyabrya $1895 \mathrm{~g}$. [Science of criminal law. Its subject, tasks, content and meaning. Introductory lecture delivered at the Demidov Juridical Lyceum on September 15, 1895]. In: Piontkovsky A. A. Izbrannye trudy [Selected Works: in 2 volumes. Vol. 1]. Kazan: Kazan University Publishing House, 2004, pp. 179-192.

12. Piontkovsky A. A. Ugolovnoe pravo (posobie k lektsiyam). Chast' Obshchaya. Vyp. 1 [Criminal law (textbook for lectures). Part General. Issue 1]. Kazan: Typographic lithography of the Imperial Kazan University, 1913. $126 \mathrm{p}$.

13. Pustoroslev P. P. Russkoe ugolovnoe pravo. Obshchaya chast'. Vyp. 1 [Russian criminal law. A common part. Issue 1]. 2-nd ed., rev. Yuriev, 1912. 252 p.

14. Komissarov V. S. (ed.). Rossiiskoe ugolovnoe pravo. Obshchaya chast' [Russian criminal law. General part]. St. Petersburg, 2005. 560 p.

15. Sergeevsky N. D. Prestuplenie i nakazanie kak predmet yuridi-cheskoi nauki (zadachi nauki ugolovnogo prava) [Crime and punishment as a subject of legal science (tasks of the science of criminal law)]. Yuridicheskii vestnik, 1879, book 12, pp. 876-904. 
16. Sergeevsky N. D. Programma nauki ugolovnogo prava [Program of the science of criminal law]. Vremennik Demidovskogo yuridicheskogo litseya, 1879, book 20 , pp. 356-382.

17. Sergeevsky N. D. Russkoe ugolovnoe pravo. Chast' obshchaya: posobie $k$ lektsiyam [Russian criminal law. General part: textbook for lectures]. 4th ed. St. Petersburg: Printing house of M. M. Stasyulevich, 1900. VIII, 364 p.

18. Sergeevsky N. D. Filosofskie priemy i nauka ugolovnogo prava [Philosophical methods and science of criminal law]. Zhurnal grazhdanskogo i ugolovnogo prava, 1879, book 1, pp. 39-87.

19. Solntsev G. I. Rossiiskoe ugolovnoe pravo [Russian criminal law]. Yaroslavl: Demidov Juridical Lyceum Publ., 1820. 302 p.

20. Spasovich V. D. Uchebnik ugolovnogo prava. T. 1 : (Obshchaya chast' ugolovnogo prava material'nogo). Vyp. 1 [Textbook of criminal law. T. 1 (General part of material criminal law). Issue 1]. St. Petersburg: Type. I. Ogrizka, 1863. 438 p.

21. Tagantsev N. S. Russkoe ugolovnoe pravo. Chast' Obshchaya: v 2-kh t. T. 1 [Russian criminal law. Part General. In 2 volumes.Vol. 1]. Tula, 2001. 800 p.

22. Feuerbach P. A. Ugolovnoe pravo [Criminal law]. St. Petersburg: Medical type., 1810. $486 \mathrm{p}$.

23. Chubinsky M. P. Obshchaya kharakteristika novykh uchenii v ugolov-nom prave: vstupitel'naya lektsiya [General characteristics of new doctrines in criminal law: an introductory lecture]. Kiev: Printing house of the Imperial University of St. Vladimir N.T. Korchak-Novitsky, 1898. 24 p. 